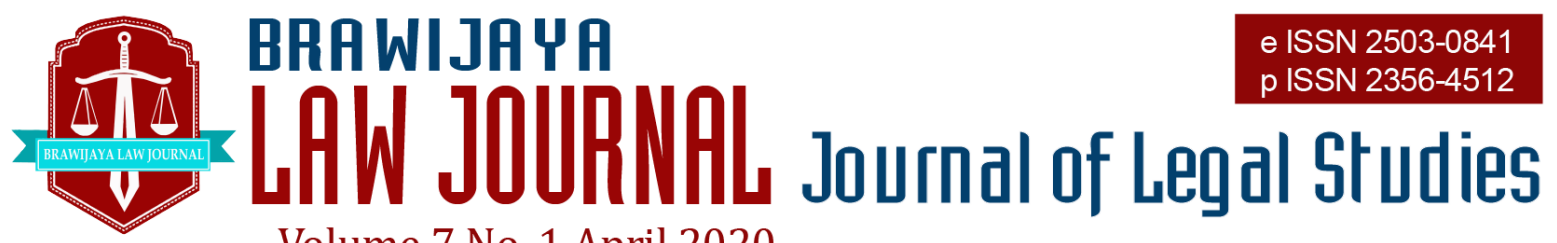

Volume 7 No. 1 April 2020

Nationally Accredited No. 30/E/KPT/2018 Dated 24th October 2018

This work is licensed under a Creative Commons Attribution-NonCommercial 4.0 International License

\title{
International Principles of Sustainable Development and the Challenges to Environmental Rights Enforcement in Nigeria
}

\author{
Murtala Ganiyu A. Murgana, Hakeem Ijaiya ${ }^{\text {b }}$ \\ ${ }^{a}$ Faculty of Law, University of Ilorin, Nigeria. \\ Email: muritalaganiyu@gmail.com \\ ${ }^{b}$ Faculty of Law, University of Ilorin, Nigeria \\ Email: hakeemijaiya@unilorin.edu.ng
}

Submitted : 2020-02-13 | Accepted : 2020-04-13

\begin{abstract}
Human existence in the environment with disregard for International Principles of Sustainable Environment has often led to overutilization of the nation's natural and environmental resources, excessive gas flaring with consequences of global warming, flood, environmental degradation, desertification, water pollution, solid waste pollution, diseases and such conditions that violate human rights to a clean and healthy environment. Necessary International and National legal instruments as well agencies have also been put in place to overcome the above problems and enhance access to environmental justice for victims. However, it observed that these instruments could still not save mankind from the threat to Sustainable Development and environmental rights. This paper examines the challenges to the enforcement of environmental rights on sustainable development in Nigeria. With the qualitative content analysis doctrinal method, the study concludes that the enforcement of human rights on environmental pollution is very poor in Nigeria. The challenges to enforcement of Environmental rights on sustainable development goals also identify with useful recommendations.
\end{abstract}

Keywords: sustainable development; human environmental rights; enforcement; challenges.

\section{INTRODUCTION}

Awareness of the concept of Sustainable Development brings about the idea of how activities of governments, corporate bodies and individuals can be frugally carried out about the exploitation of environmental resources to meet the needs of the present generation without jeopardizing the needs of the future generation. This vision well contains in the principles of Sustainable
Development, which stands for (i) Equity towards future generation or passing a clean and healthy environment to future generation (ii) Equity within our generation or addressing economic inequalities and (iii) 
Integrating Environmental Protection into development processes. ${ }^{1}$

The idea about the concept of sustainable development is based on the experience that a man in his quest for survival on the environment had to engage in a lot of activities such as mining of mineral resources, petroleum exploration, industrialization, felling of trees in the forest, stone blasting in the quarry, Aviation transportation, etc., all of which their overexploitation have resulted in environmental consequences like global warming, flooding, and erosion, environmental degradation, desertification, environmental pollution, poverty and diseases with impending danger of infringing on the needs of the future generation. ${ }^{2}$ It is sad to know that the above act of disregard for environmental sustainability is not limited to individuals alone but also perpetrated by the government and corporate organizations in Nigeria.

To reduce instances of unsustainable use of the environmental resources, a legal approach of using international legal instruments at the United Nations was put up to facilitate the implementation of the law on sustainable development, and Enforcement of Human Rights to clean and sustainable environment with the hope of bringing back sanity into the use of environmental resources and bringing conformity with the International Principles of Sustainable Development. This approach considers plausible since the concept of Human Rights which involves the attainment of alienable rights of people to a good life, and a healthy environment is also found compatible and embraced by the concept of Sustainable Development.

Despite the above measure, it is still generally observed that the problem of sustainable Development continues in Nigeria with overexploitation of the natural resources, continuous gas flaring, constant flooding and general neglect for solid waste pollution thereby subjecting the earth

Edith Brown Weiss (ed), Environmental Change And International Law, (United Nations University Press, 1992), 385. population and environment to degradation, unhealthy environment, inequality, and poverty while the issue of enforcement of human rights to environmental remedy for abuse of sustainable development goals remains a far cry.

The purpose of this paper is to examine the challenges to enforcement of human rights on the attainment of Sustainable environmental in Nigeria. The paper divides into eleven parts for ease of discussion: Section one contains Introduction; Section two discusses the Concept, while section three explains the principles of Sustainable Development. Section four is about International and Regional Instruments, for promoting sustainable Development, Section five explains the Regulatory Framework for the promotion of Sustainable Development.

\section{LEGAL MATERIALS AND METHODS}

This paper uses the qualitative content analysis doctrinal method to analyses the problem that arises regarding the environmental problem in Nigeria. It also analyses legal approach of Nigerian legal instruments and international legal instruments at the United Nations was put up to facilitate the implementation of the law on sustainable development, and Enforcement of Human Rights to clean and sustainable environment with the hope of bringing back sanity into the use of environmental resources and bringing conformity with the International Principles of Sustainable Development. It also used several cases regarding the environmental rights enforcement and sustainable development principle in Nigeria to explain and analyses the situation in Nigeria

\section{RESULTS AND DISCUSSIONS}

\section{Concept of Sustainable Development}

According to the United Nations (UN) World Committee on Environment and Development, sustainable development

\footnotetext{
2 Violet O. Aigbokhaevbo, 'International Environmental Law Principles' (2010) 1 Sustainable Challenges University of Benin Journal of Private and Property Law, 10.
} 
defines as: "Development that meets the need of the present without compromising the ability of the future generations to meet their own needs' ${ }^{\prime 3}$. Based on the definition, it implies that the definition recognizes the right of future generations to achieve Sustainable Development and the right to utilize natural resources judiciously. Sustainable Development also means the idea of building and managing our community in a frugal manner so that we can live in it comfortably without consuming all the resources within it. In line with the above view, Tayo Akeem Yusuf explains Sustainable Development to mean a kind of Development that makes for improvement in the quality of human life within the capacity of earth resources. ${ }^{4}$

Sustainable development is "also a policy by which the environment can be protected from pollution, degradation, and or restored, replaced or resituated after degradation"5. It involves economic and development activities that meet the needs of the present generation without compromising, reducing or destroying the ability of the future generation to meet their needs. Sustainable development has been described to be an ancient concept that embraces international law and requires that any development undertaken takes into consideration the needs of the current generation without endangering the needs of the future generations to benefit from it. ${ }^{6}$ Judge Weeramantry, in the GabcikovoNagymaros's case, explains that:

3 The Brutland Report, World Commission on Environment and Development: (WECED) Our Common Future, (New York, Oxford University Press UN DocA42/47, 1987). Agenda 21, 15.

4 Yusuf A.T, Implementing the nine Principles of a Bustainable Society: Can Nigerian Government Deliver?(2009)

$<$ http//www.nigeriansinamerica.com/article/264/1 /implementing the- nine- principles of -asustainable society-can- nigerian governmentdeliver/page1.htm> accessed 26/1/2020.

5 Fagbemi Sunday Akinlolu, 'The Concept of Sustainable Development: A Double-Edged Sword', (2012) NIALS Journal of Law and Public Policy, Meiden Edition, 122.

6 Alan Boyle, 'Human Rights and the Environment: Where Next?', (2012) 23(3) The European Journal of International Law, 629.
"Sustainable development is thus not merely a principle of modern international law. It is one of the most ancient of ideas in human heritage. Fortified by the rich insights that can be gained from millennia of human experience, it has an important part to play in the service of international law."7

It, therefore, follows that for any development project to be considered sustainable, it should actively and meaningfully involve the individuals, and they should benefit from it without compromising the ability of the future generation to benefit too, ${ }^{8}$ and that principle should internationally Practice among nations.

The three pillars of Sustainable Development include Economic, Social and Environmental activities that promote the ability of the present and future generations to live within the earth's capacity and support as follow: ${ }^{9}$

a. Economic: This means an economically sustainable system must be able to produce goods and services continuingly, to maintain manageable levels of government and external debt, and to avoid extreme sectoral imbalances which damage agricultural or industrial production.

b. Environmental: Quotes that an environmentally sustainable system must maintain a stable resource base, avoiding over-exploitation of renewable resource

7 Gabcikovo-Nagymarmos Project (Hungary v Slovakia), ICJReporte (1997), 7, separate opinions, 88.

8 Jonathan Verschuuren, 'Sustainable Development and The Nature of Environmental Legal Principles', (2006) (9)1 Potchefstroom Electtronic Law Journal, 24.

9 Justice Mensah, Sustainable Development: Meaning, history, principle, pillars, and implications for Human Action: Literature Review, Cogent Social Science, 20019,p.9 See also: Haris, Jonathan M., Basic Principles of Sustainable Environment: Global Development, (an Environmental Institute Working Paper 00-04, 2000). 
systems or environmental sink functions, and depleting non-renewable resources only to the extent that investment is made inadequate substitutes. This includes maintenance of biodiversity, atmospheric stability, and other ecosystem functions not ordinarily classed as economic resources.

c. Social: means that a socially sustainable system must achieve distributional equity, adequate provision of social services, including health and education, gender equity, and political accountability and participation.

The main objective of Sustainable development as indicated in the pillars above is to ensure Economic Development, Social Equity and Justice and Environmental Protection. These three pillars of sustainability introduce many potential complications to the original simple definition. The goals expressed or implied are multidimensional, raising the issue of how to balance objectives and how to judge success or failure. ${ }^{10}$ For example, what if the provision of adequate food and water supplies appears to require changes in land use, which will decrease biodiversity? Assuming the non-pollution sources are more expensive, thus increasing the burden on the poor, for whom they represent a larger proportion of daily expenditure? Which goal will take precedence?

However, Sustainable development is observed to be highly related to the environment. Since, the three issues involved are environmental management, environmental resource analysis/evaluation, and environmental protection and conservation. Accordingly, Habitat 1994, stated in its elaboration that sustainable development "emphasizes how decisions and actions today can affect the future, especially about natural resources availability, environmental health and destruction, and

10 Christina Voigt, Sustainable Development as a Principle of International Law: Resolving Conflict between Climate Measure and WTO Law, (Martinus Nuhoff Publisher, Leiden, 2009), 4.

11 Habitat 1994: Sustainable Human Settlement Development Implementing Agenda 21, Nairobi, Habitat. global ecosystems"11. Therefore, Sustainable Development is fundamentally concerned with the two-way relationship between development and the environment. Based on the explanation above, it is now clear that more attention has to be exercised to live a balanced life within the environment that should be kept away from destruction.

The environment is the focal point in the drive for development in various sectors and institutions, stressing that there would be no development without the environment. When the World Commission on Environment and Development presented its 1987 report, "Our Common Future", It sought to address the problem of conflicts between environment and development goals by formulating a definition of sustainable development. ${ }^{12}$

\section{The Threats to Sustainable Development in Nigeria}

The poor state of Solid waste pollution arising from indiscriminate dumping of domestic wastes on the highways and public places in almost all the major cities of Nigeria including the Federal Capital Abuja which has now culminated into the outbreak and spread of Lassa Fever epidemic to nineteen states out of thirty states of Nigeria is a great threat to Sustainable Development and the quest of national policy on Environment to live under a clean and healthy environment in Nigeria ${ }^{13}$. Presently, Lassa Fever has claimed 41 lives in Nigeria while many cases of Lassa Fever are reported to have spread to Bauchi, Adamawa, Taraba, Kano, Lagos, Kogi, Edo, Ondo, Ogun states among others. ${ }^{14}$

Persistent cases of oil pollution on water, rivers, aquatic lives and land in Ogoni land in the Niger Delta States of Rivers, Bayelsa, Delta, Cross River the Ondo States, etc through the activities of petroleum oil drilling companies are presently standing a

12 Obafori, Ekpu and Ojealaro, 'An appraisal of the Concept of Sustianable Environment Under Nigerian Law',(2009) 28(2) J. Hum Ecol, 135.

13 Channels Television News Headlines at 8PM, Friday 24 January, 2020.

14 Channels Television News Report at 10Pm, Tuesday 28 January 2020. 
great threat to sustainable development in Nigeria. Continual flaring of gas by the oil companies in the Niger Delta area of Nigeria without a serious legal control in Nigeria has continued to add to Nigeria's problem of the problem of global warming, climate change, air pollution, respiratory disease, flood, erosion, desertification, death of animals and extinction of wildlife and trees in the forest. In 2018 and 2019, a lot of people in Port Harcourt and parts of Rivers State suffered serious air pollution from the outbreak of soot, which emanated from persistent flaring of gas. The soot attack prevented people from getting access to fresh and clean air for breathing. ${ }^{15}$

Rampant cases of conflict over the destruction of farmland and search for grazing land between the Fulani cattle herders and food crop farmers in Benue, Plateau, Kaduna, Nasarawa, Kogi, Ekiti and the Ondo States of Nigeria is part of the climate change problem and a threat to sustainable development that needs to be addressed in Nigeria. Continuous illegal felling of trees in the forest reserves by forest poachers and indiscriminate killing of animals in the game reserves by game poachers in Nigeria thereby leading to increasing problems of desertification and extinction of wildlife are current threats to Sustainable Development in Nigeria. The current lack of interest in implementing treeplanting programs by the Federal and State governments as well as private individuals in Nigeria has led to non-replacement of trees illegally felled for housing construction and making charcoal. This has led to a grave problem of desertification and a threat to sustainable development in Nigeria. For example, in BauciState of Nigeria, it is reported that deforestation is having a grave effect on the environment in the state as almost all the trees in the forest reserves in the state have lost to activities of tree cutters. It is further reported that though the state's law makes indiscriminate felling of trees an

15 Channels Televiision Environmental Report, Wedneday, 16 October 2019.

16 Channels Television Environmental Report, 2020.

17 United Nations Conference on Human Environment, "Stockholm Declaration" (16 unlawful act, its implementation is not certain. ${ }^{16}$ All the above therefore require effective implementation of a necessary legal regimes to restore Sustainable Development in Nigeria.

\section{International and Regional Instrument for Promotion of Sustainable Development}

International legal instruments take the form of a treaty (also called the agreement, convention, or protocol) that binds the contracting states to the negotiated terms. The process of ratification of an international treaty to become national law involves an agreement with the treaty by the ratifying state and the international body. However, a treaty has to be ratified by an Act of the national assembly of the ratifying country before it becomes part of the national law of that country. The international treaties, declarations, and commitments that address human rights and sustainable development include:

\section{a. Stockholm Declaration on Environment 1972: ${ }^{17}$}

The need to conserve global resources through the adoption of the International Principles of Sustainable Development started with the Stockholm Declaration of 1972. This was the United Nations Conference on Human beings and Development of Environment. As contained in its Brutland Report, Agenda 21 of the Stockholm Declaration conceded to nations the need for nations to explore their resources within their environmental jurisdiction based on their policies. The above marked the beginning of the adoption of a legal regime to drive the policy for sustainable development of the environment.

\section{b. The Rio Declaration on Environment and Development 1992: ${ }^{18}$}

This Rio de Janeiro United Nations Convention in Brazil is a more direct global international convention that presses for

June1972),UN.Doc.A/Conf.48./14 /Rev.1 (UN. Pub. 73.11.A.14), 10.

18 The United Nations Conference on Environment and Development "The Rio Declaration" UN.DocA/Conference.48/Rev, 20 . 
global adaptation of the principles of Sustainable Development. It was a departure from the conservative attitude of individual states to a more liberal appreciation of the universal danger of the environment. In this declaration, environmental conservation is regarded as a key element to sustainable development, it also emphasizes the need to ensure development projects meet the needs of both present and future generations. This declaration further, emphasizes the importance of poverty eradication as a means to achieve development and spells out the duties of states to protect their natural environment

\section{c. The United Nations Convention on the rights of Child ${ }^{19}$}

It is a common concern that most of the global international instruments on human rights do not mention the environment because they were drafted before the emergence of environmental law. However, Article 24 of the UN Convention on the Right of Child speaks of the provision of clean drinking water and the dangers of pollution. The above provision can be claimed to speaks in support of Sustainable Development.

\section{d. African Charter on Human and Peoples Rights (1987). ${ }^{20}$}

The African Charter on Human and People's Rights, a regional legal instrument for promoting Sustainable Development states in article 24, that "all people shall have the right to their economic, social and cultural development with due regard to their freedom and identity and in the equal enjoyment of the common heritage of mankind." It is observed that the provisions of the African Charter on Human and Peoples Rights are the first international instrument on human rights to contain an explicit guarantee of environmental quality. Other articles within the Charter that address the

19 THE Unite Nations Convention on the Rights of the Child November 20 1989, article 24.

20 African Charter on Huma and Peoples Rights, Article 24.

21 National policy on Environment in Nigeria 1988, Paragraph 30(A). rights of people to participate democratically in their government; to work with equal pay and benefits; to enjoy physical and mental health and well-being; to receive an education with due respect and protection for traditional values. All of these rights are to be enjoyed in an environment that is favourable for development.

\section{Regulatory Framework for Promotion of Sustainable Development in Nigeria}

The national regulatory framework relevant for the promotion of sustainable development of the environment in Nigeria include the National Policy on Environment, the Constitution of the Federal Republic of Nigeria 1999 (As amended), the NESREA Act, the Environmental Impact Assessment Act, and the State Environmental Protection law in Nigeria.

The National Policy on Environment in Nigeria is specifically to promote Sustainable Development. Paragraph 30(a) of the policy seeks for the enactment of a law for achieving sustainable development in Nigeria ${ }^{21}$. The Constitution of the Federal Republic of Nigeria 1999 (As amended) is another national legal instrument that seeks for the promotion of Sustainable development. Section 20 of the Constitution provides that "the State shall protect and improve the environment and safeguard the water, air, and land, forest, and wildlife of Nigeria'22. Although the 'right' provided under this section is not justice able, it, however, recognizes the need for embracing the International Principles of Sustainable Development. The National Environmental Standards Regulations Enforcement Agency (NESREA) Act 2007 has its provisions on S.1 (2) dedicated to promotion to sustainable Development in Nigeria, particularly, the natural resources. ${ }^{23}$ This act which focuses on the protection and development of natural resources in Nigeria, and covers a lot of areas of environmental concern such as monitoring

22 The Constitution of the Federal Republic of Nigeria 1999(As amended), Section 20.

23 The National Environmental Standards Regulations Enforcement Agency Act 2007, section 2(1). 
of environmental standards and regulations on air, land, water body, forest, and sea, biodiversity excluding the oil and gas sector. The Act gives power to the agency to make and review regulations on air and water quality, control of harmful substances, and other forms of pollution, all of which are geared towards a sustainable environment.

The Environmental Impact Assessment Act (EIA) is another legislation for the promotion of Sustainable development. The significance of the Act is to ensure a sustainable environment by assessing the potential impact of proposed public and private sector projects on the environment before embarking on the construction of such projects. ${ }^{24}$ The specific amount of money is to be paid as fine for non-compliance with the provisions of EIA.

The National Environmental (Soil and Flood Control) Regulations 2011 aims at achieving a sustainable environment through restriction of land-disturbing activities and usage that are harmful to human health and the environment. ${ }^{25}$ The Mineral Act is another law that aims at achieving a Sustainable Environment. The Act requires from the mining investor, submission for approval, relevant documents on mining environmental compliance of project to the Mines Compliance Department. There is also, the State Environmental Sanitation and Protection law for protecting the thirty states of Nigeria against environmental pollution and other activities that will affect Sustainable Development.

However, it should be known that the application of these laws, for achieving Sustainable Development in Nigeria is faced with some limitations. Section $2 \mathrm{O}$ of the Constitution of Federal Republic of Nigeria 1999(As amended), which seeks for living under a clean and healthy environment falls under section two of the constitution which makes it legally unenforceable. The power of the NESREA Act which covers other forms of pollution, however, limited as it can't

24 Environmental Impact Assessment Act1992, Section 14.

25 National Environmental (Soil and Flood Control) Regulations 2011. apply to incessant air pollution of gas flaring from the oil sector in the Niger Delta area.

Other environmental provisions of the Act suffer weak enforcement considering the poor state of the environment and public health arising from solid waste pollution and the outbreak of Lassa fever and Cholera in Nigeria. ${ }^{26}$ Also, rampant reports on indiscriminate felling of trees in the forest for building construction and burning of wood for charcoal supply which has caused serious deforestation in Nigeria. This shows that the NESREA Act is far from achieving the objectives of a sustainable environment in Nigeria. Failure of the Environmental Sanitation law in the thirty-six states of Nigeria, including Abuja and the state Environmental Protection agencies to overcome the ever-increasing problem of an indiscriminate solid waste dump in Nigeria, also shows that the limitation of the law in achieving Sustainable Development. The Environmental Impact Assessment Act also suffers the serious problem of noncompliance from the public and private sector in Nigeria going by the spate of complaints on how erosion has caused the collapse of public bridges on Federal roads in Adamawa, Bauchi Taraba, Bayelsa, Delta Benue, and Kwara states, while lack of proper compliance with project requirements there are report of incessant building collapse and gas explosion in gas outlets in Lagos State, Anambra, Kwara, Kano, Ogun States and other parts of Nigeria. ${ }^{27}$

\section{Environmental Rights}

The concept of Human rights is very wide and has been defined in many ways. Contemporarily, Human rights are the rights that are recognized as legitimate to human beings globally and not a privilege. The rights are usually divided into two categories: (1) civil and political rights, and (2) economic, social, and cultural rights. Civil and political rights ensure moral and political order and include the right to life, participation, and equality. Moreover,

26 Obi Ogbalu, 'Environtal Regulation in Nigeria' 10 (6) Oil and Gas Law and Taxation Review, 25.

27 Channels Television Environmental Report November, 2019. 
economic, social, and cultural rights maintain principles for an individual's well-being. Therefore, environmental rights fall within the second category of the above.

Environmental Rights is an aspect of Human Rights that centres on the rights of human beings while existing in the environment and it focuses on the rights of human beings to clean a healthy and sustainable environment. ${ }^{28}$ Following careful study of human rights, it is observed that apart from the UN Convention on the Rights of the Child that guarantees clean drinking water and protection from risks of pollution, no other Human Rights treaty proclaims general rights to environment Environmental rights are majorly implied as part of socioeconomic rights, as they are not explicitly present in most of the international instruments.

However, recent developments have shown that Environmental Rights are now contained in Article 24 of the African Charter on Human and Peoples Rights. The African Charter on Human and Peoples Rights is observed today as the first international instrument that contains a clear guarantee for the protection of the environment. The efficacy of these rights was tested in a case between the People of Ogoni Land v Federal Government of Nigeria. The petition filed before the African Commission on Human and Peoples Rights was on violation of rights to a satisfactory environment by the Federal Government of Nigeria through the uncontrolled activities of the foreign oil companies. The Commission acting on the petition and applying the articles for control on the provision of a satisfactory environment held that the Federal Government of Nigeria had violated the Charter guaranteed right to a satisfactory environment favourable to development.

\section{The Interdependence of Environmental Rights and Sustainable Development}

Sustainable development is highly related to the environment. The three issues

28 The adopted Aarhus Convention of June 251998 can be regarded as a kind of environment a agreement as it links Environmental Rights and Human Rights and acknowledges that present involved in the relationship are environmental management, environmental resource analysis/evaluation, and environmental protection/conservation. Also, Habitat 1994, stated in its elaboration that sustainable development "emphasizes how decisions and actions today can affect the future, especially about natural resources availability, environmental health, and destruction and global ecosystems".

$$
\text { Sustainable development is }
$$

fundamentally concerned with the two-way relationship between development and the environment. It is now clear that more attention has to be exercised to live a balanced life within the environment that should be kept away from destruction. Sustainable human development seeks to expand choices for all people, including men, women, and children of the present and future generations while protecting the natural systems on which all life depends.

Moving away from a narrow, economy-centred approach to development, sustainable human development places people at the core and views humans as both a means and an end of development. Thus sustainable human development aims to eliminate poverty, promote human dignity and rights, and provide equitable opportunities for all through good governance, thereby promoting the realization of all human rights economic, social, cultural, civil and political.

The promotion of environmental rights is particularly relevant in the context of globalization and its potential for excluding and marginalizing weak members of the international community and people with limited resources, most especially the indigenous people. Environmental rights afford protection against such exclusion and marginalization. Sustainable Development and Environmental Rights are found related in the sense that if development is unsustainable whereby people's health is endangered due to environmental degradation and pollution, where rule of law

generation owes the future generation see http://www.unece.org/envy/welcome.html,access ed January 26. 
and equity do not exist; where natural resources are confiscated or denied under whatever guise; or where large numbers of people live in abject and degrading poverty. Similarly, environmental rights are enhanced when equity or poverty reduction programs or development meets the need of the present without compromising the ability of future generations to meet their own needs. ${ }^{29}$

The view about the linkage between Environmental Rights and Sustainable Development has, however, been endorse in the functions of many international Human Rights Organizations. The Universal Declaration of Human Rights is its linking of rights with responsibilities for Sustainable Environment, states that it is the responsibility of every individual and every organ of society to promote respect for human rights and to secure their universal recognition and observance and that all human beings should relate with one another in a spirit of brotherhood. Article 29 states:30"Everyone has duties to the community in which alone the free and full development of his personality is possible." These concepts form the Universal Declaration are important in the context of sustainable human development; by implication, social capital is a critical factor for development, and full development of man is only possible in a conducive environment.

Moreover, the Rio Declaration on Environment and Development 1992 introduces environmental conservation as a key element to sustainable development. According to the Rio Declaration, development projects must meet the needs of both present and future generations. This means that humans need to have the ability to live "a healthy and productive life in harmony with nature". This declaration also emphasizes the importance of poverty

29 Tim Hyward, Constitutional Environmental Rights, (New York, Oxford University Press, 2005), 7.

30 Universal Declaration of Human Rights 1948, Article 29.

31 In July 1994 Fatimah Zohra Ksentini, submitted a final report of the UN on Human Rights and the Environment. Mrs Ksetini, the special UN Rapporteur on Prevention of Discrimination and eradication as a means to achieve development. Moreover, the 1986 UN Declaration on the Right to Development states that development is a human right. That proclamation was strengthened by the Declaration of the 1993 UN World Conference on Human Rights, which says that "the right to development is an inalienable human right and an integral part of fundamental human freedoms." The UN global conferences on population and development (Cairo) and women (Beijing) and at the World Summit on Social Development (Copenhagen) further confirmed the above view.

The indivisibility of Environmental Rights and Sustainable Development has also summarized by Special Rapporteur Fatma Zohra Ksentini and accompanied by a Draft Declaration of Principles of sustainable Environment. ${ }^{31}$ Also, a series of reports have been received by the UN Human Rights Commission from Ms. Ksentini on the narrower topic of the impact of toxic and dangerous products and wastes on human rights. Also, regional and-international tribunals have allowed victims to bring cases based on rights violations caused by environmental harm, and some national tribunals have accepted suits claiming violations of a right to a healthy environment. $^{32}$

Notwithstanding the above developments, no binding international agreement has had environmental rights as its primary focus. Also, the issue continues to suffer from in attention because that it fails to fit neatly within the agenda of either the human rights movement or the environmental movement. Few international human rights organizations have programs devoted to this set of rights; likewise, movements focused on protecting the environment do not generally have as their

Protection of the minorities made her final submission in response to a demand for sub commission report on how to overcome the problem of environment in relation to human rights.

32 See Allan Boyle and Michael Anderson (eds) Human Rights Approach to Environmental Protection, (Oxford University Press, 1996), 20. 
aim the more human-cantered goals of environmental rights, which commonly include social justice issues such as the disproportionate suffering of poor, indigenous, and minority communities from toxic industrial activity. Even the environmental justice movement in the United States predominantly limits its scope to situations occurring within the nation's borders. ${ }^{36}$

\section{Environmental Human Rights Enforcement in Nigerian Courts}

Environmental human rights include those basic human rights that pertain to minimum biological requirements, notably of food, water, and shelter; and the civil and political rights that enable individual and group participation in the creation of institutions that ensure social and ecosystemic viability. In past eras, when economies and societies were place-based, these rights were mutually interdependent. In today's world, where cultural identity is fluid and involves membership in multiple communities, and where economies are shaped by global as well as local forces, control over local resources is rarely in local user hands. ${ }^{33}$

Individual and group efforts to secure necessary environmental human rights often conflict with broader governmental efforts to control natural resources. Such conflicts can be characterized as environmental human rights abuses when political and economic institutions and processes: (1) wrest control over traditionally-held resources without negotiation or compensation, or when such institutions continue actions that knowingly harm the critical resources that sustain a cultural way of life; (2) degrade the environment, and place individuals and populations at risk. To avoid the above precarious condition, enforcement of human environmental rights through the court of law is therefore considered the legal and legitimate way out.

Protection of fundamental rights of citizens and where necessary balancing the

\footnotetext{
33 Oluwatoy in Adejowo-Osho, Evolution of Human Rights Approach to Environmental Protection, 22. $34\{1996\}$ 4NWLR(pt445) 657.
}

conflicting interests of parties in a dispute are part of the core duties of courts. This position was attesting to in the case of Olawoyin $v$ Attorney General of Nigeria, where it held that the court has the power and jurisdiction to safeguard Nigerians and prevent infringement of such rights. Buttressing the above, section 46(1) and 2 of the Constitution of Federal Republic of Nigeria 1999(As amended) states that any person whose right has been or likely to infringe upon can seek a remedy in a court of law. Similarly, the Fundamental Rights (Enforcement Procedure Rules) 2009 also made for the regulation of rules of Practice and Procedure for the enforcement of Human Rights in Nigeria.

Experience in Nigeria shows that the oil sector, where environmental degradation is most prevalent, the all-pervading influence of the oil companies and (he paternalistic attitude of the judges towards them in matters relating to environmental hazards created by the companies have made the enforcement of environmental laws ineffective. Contrary to the Indian situation where an act damaging the environment ordered to cease by the court despite the significant loss of investment that would occur, the situation in Nigeria had been different until quite recently. The Nigerian judiciary has been reluctant to give orders compelling companies whose operations are damaging the environment to cease the actions complained of. The consideration of the potential loss of revenue and investment outweighs considerations for the protection of the environment. This is due largely to the fact that the Nigerian economy is dependent on the revenue from the sale of crude oil. Several oil-related cases filed in the courts in Nigeria alleging pollution from oil exploration, loss of income, loss of property, contamination of drinking water leading to water-borne diseases and pollution of land had been lost in court for lack of locus standi or declared un-justiciable instead of considering the effects of environmental damage. In the cases of Shell v, TieboV11 ${ }^{34}$, Shell v. Isaiah, ${ }^{35}$ "Seismograph Services v. Mark $^{36}$, Ogiale v. Shell, ${ }^{37}$ Shell v.

\footnotetext{
35 \{1997\} 6NWLR(pt508)226.

36 \{1993\}7NWLR(pt304)293.

37 \{1997\}1NMLR(pt480).
} 
Ambah. ${ }^{38}$ The general characteristics that run through all the above-mentioned cases are all claims for compensation for the operation of oil companies in their local communities; they are usually oil spillage claims for loss of income from fishing and farming, pollution of drinking water, damage to farmlands and the environment.

Also, in J. Chinda \& Ors v Shell BP Petroleum Company of Nigeria Ltd, the plaintiff's claim that a lot of damage had done to his economic trees, land, and house as a result of negligence in the control and management of the defendant's gas flare site which located within a short distance to the plaintiff's house. The court's decision on this case was that the plaintiff failed to produce evidence of negligence in the defendant's operation, and the action failed. The case of Amos v Shell BP Petroleum is another test on the rejection of environmental human rights. This case is of relevance in the sense that it involves the issue of Public Nuisance and Locus Standi. ${ }^{39}$ In this case, the plaintiff's action against the defendant alleging that the erection of a temporary dam across the entire Ogba community caused severe floods on the community land and the creek to the extent that the community members could not paddle their canoes and transport goods and people to the market. The court decided the case against the plaintiff on the ground that the creek was public water, and the act of blocking the creek was a public nuisance, unless the plaintiff had unusual proof that he suffered special personal damage from interference with public rights, his claim lacked merit in court. The court overlooked the issue of the flood, which was environmental damage in the case and considered the issue of locus standi.

There is also the case of Joel Odim \& Ors v Shell BP over cleaning oil from river water in Ogoni land, which not upheld in court for many years. The above defects explain why the enforcement of

38 \{1999\}3NWLR(PT593).

39 The term Locus Standi refers to legal capacity to institute proceding as per Justice Fatai Williams I the case of SenatorAbrahamAdesanya v President Federal Republic of Nigeria. environmental rights is weak in Nigeria. Although it is now a fact from the above that securing access to human environmental rights is weak in Nigeria, it equally observes that there are few cases where the courts in Nigeria have upheld decisions in of consideration for sustainable development and environmental rights: Such include the case of Shell Petroleum Development Company $\mathrm{v}$ destruction of economic trees and loss of animals in Ofugbene, Burutu Local Government Area of Edo State due to spillage of crude oil from the defendant's/appellant's Trans Forcadoe Petroleum oil pipeline that was laid over the land of the plaintiff/respondents. Having lost this case at the first instance at the lower court on the ground of reasonable evidence to prove the negligence, the plaintiff/respondent eventually won the case as the appeal court on the ground of want of care. In Umudje $\mathrm{v}$ Shell Petroleum Development Co (Nig) Ltd. $^{40}$ The trial judge held the defendant liable for negligence for the construction of culverts, which blocked water passage and resulted in drying up of lakes and destruction of fishes in the ponds of the plaintiff. ${ }^{41}$ There is also the case of AG Lagos v A.G Federation and 3 Ors (2003), ${ }^{42}$ where a decision in the case based on consideration for sustainable development and the case of Oronto Douglas v Shell $\mathrm{BP}^{43}$ which decided in favour of the plaintiff. Apart from the above few cases, it generally observes that achieving effective enforcement of environmental rights on violation of goals of International Principles of Sustainable Development in Nigeria is still a big challenge that needs to surmount with all seriousness.

\section{The Challenges to Enforcement of Human Rights $n$ Application of International Principles of Sustainable Development in Nigeria}

40 See Adeoye, R.O., Environmental Rights and Sustainable Development, (LLM Seminar Paper, Faculty of Law, University of Ilorin, Nigeria), 15.

$41 \quad\{20000\} 10$ NWLR248.

$42\{2003\} 6$ SC 24.

$43\{1998\}$ LDELR6457(CA). 
The unenforceability or non-binding status of the provisions of Section 20 of the Constitution of the Federal Republic of Nigeria (As amended) is a big legal challenge to enforcement of environmental rights in Nigeria. The Constitution of Nigeria does not grant an express right to a healthy, clean environment. Section 20 of the Constitution of the Federal Republic of Nigeria 1999 provides that 'the State shall protect and improve the environment and safeguard the water, air, and land, forest, and wildlife of Nigeria'44. The 'right' provided under this section is not justice able; it cannot be relied upon by a plaintiff in an environmental violation case in the court of law.

It is only in Section 33 of the Constitution that provides for the protection of fundamental rights to a good life. Whether the courts in Nigeria will be ready to consider this view in cases bothering on enforcement of environmental rights as it did in other jurisdictions like India is another issue entirely.

Lack of compliance with the law on environmental protection is another legal challenge to the realization of environmental rights in Nigeria. Particularly, Federal and state governments have identified as the worst offenders for not implementing or keeping to the rules and laws on environmental protection. For example, both the federal environmental regulation agency(NESREA) and State Environmental Protection Agencies in the 36 states of Nigeria including the Federal Capital Territory in Abuja are presently guilty of negligence and failure to dispose or make adequate provision for disposal of everincreasing urban solid waste in their respective states thereby contributing to the poor state of environmental sanitation and further denying people access to clean, safe and healthy environment as provided in the

44 Emanuel E. Okon, The Legal Stts of Sustainable Development in the Nigerian Environmental Law <http://dx.doi.org/10/4314/jsdplv712.6accessed on 25 , January 2020, 116.

45 Ibid.

46 Orji Uchenna Jerome, 'Enchancing the Implementation of Sustainable Development in Nigeria through Legal Strategies', (2012) 8(1)
Constitution and relevant environmental legislation in Nigeria. ${ }^{45}$

Also, these government agencies are guilty of non-compliance with the Environmental Impact Assessment Act on government project, which now results in more problems of environmental degradation, erosion, and building collapse in Nigeria. The access to enjoyment and enforcement of environmental rights in Nigeria will be more enhanced if both the government and their agencies learn to do their bidding by complying with the environmental law and regulations.

The concentration of power of Locus Standi on governments and government agencies over matters of public nuisance and environmental governance by courts in Nigeria is another legal challenge to enforcement of environmental rights in Nigeria. ${ }^{46}$ Since it is only the National Environmental Standards Regulation Enforcement Agency (NESREA) and the States- Environmental Agencies that have to enforce power environmental law and policies in Nigeria, non-government agencies and individuals do not have locus standi to bring claims for enforcement of environmental law for public environmental degradation based on the principles of Sustainable Development. This approach will continue to be a set-back to the realization of environmental justice in Nigeria and possibly the main reason why Nigerian environmentalists seek environmental justice outside Nigeria, as in the case of Saro-Wiwa and 9 Ors v Royal Dutch Petroleum Company. ${ }^{47}$

Other challenges include the poor attitude of people at reporting activities that involve environmental violations in court but rather resulting in self-help or militancy as displayed in many parts of the Niger Delta Area in Nigeria. Poor enlightenment, lack of

Consilience: The Journal of Sustainable Development, 93.

47 Mohammed Tawfiq Ladan, Legal Issues in Environmental Sanitation and Waste Management in Nigeria: Role of Environmental Courts, A (Seminar paper presented to Magistrateson Environmental Sanitation Law, National Institute of advanced Legal Studies Abuja Nigeria, 2015. 
information, and lack of understanding of the need to enforce environmental rights by members of the public over incidences of environmental pollution have constituted another challenge to enforcement of environmental rights on sustainable Development in Nigeria. ${ }^{48}$

\section{CONCLUSION}

Having found that both the concept of Sustainable Development and Human Rights are strongly interrelated, the study examined cases on the enforcement of environmental rights on implementation of International Principles of Sustainable Development as it relates pollution and degradation of the environment in Nigeria and concluded that enforcement of environmental rights on environmental pollution and degradation cases is still weak due to a lot of challenges. It found that unenforceability of Section 20 of the Constitution of Federal Republic of Nigeria 1999(As amended)lack of compliance with environmental protection law and regulations by Federal and State governments environmental protection agencies, poor attitude of people at reporting cases of environmental violations, poor and lack of information enlightenment on enforcement environmental rights are the challenges confronting enforcement of environmental rights on the International Principles of Sustainable Development.

Accordingly, it recommended that section 20 of the constitution of the Federal Republic of Nigeria 1999 should be amended to become enforceable or transferred to Section 33 of the Nigerian Constitution to become part of the enforceable fundamental human rights to life. Also, there should be effective compliance with environmental protection laws and regulations in Nigeria by the Federal and state government's Environmental Protection agencies. There should be devolvement of concentration of power Locus Standi on federal and governments in Nigeria to create room for public-private participation in environmental litigations. There should be more enlightenment activities for improving awareness and participation of private individuals in the enforcement of environmental rights on violation of Principles of sustainable development.

\section{REFERENCES}

\section{Book and Report}

Boyle, Allan and Michael Anderson (eds) Human Rights Approach to Environmental Protection, (Oxford University Press, 1996)Weiss, Edith Brown (ed), Environmental Change And International Law, (United Nations University Press, 1992)

The Brutland Report, World Commission on Environment and Development: (WECED) Our Common Future, (New York, Oxford University Press UN DocA42/47, 1987)

Tim Hyward, Constitutional Environmental Rights, (New York, Oxford University Press, 2005).

Voigt, Christana, Sustainable Development as a Principle of International Law: Resolving Conflicts between Climate Measures and WTO Law, Martinus Nuhoff Publishers, Leiden, 2009.

\section{Journal}

Aigbokhaevbo, Violet O., 'International Environmental Law Principles', (2010) 1 Sustainable Challenges University of Benin Journal of Private and Property Law.

Akinlolu, Fagbemi Sunday, 'The Concept of Sustainable Development: A DoubleEdged Sword', (2012) NIALS Journal of Law and Public Policy, Meiden Edition.

Boyle, Allan, 'Human Rights and the Environment: Where Next?', (2012)

23(3) European Journal of

International Law.

Jerome, Orji Uchenna, 'Enchancing the Implementation of Sustainable Development in Nigeria through Legal Strategies', (2012) 8(1) Consilience: The Journal of Sustainable Development. 
Obafori, Ekpu and Ojealaro, 'An appraisal of the Concept of Sustianable Environment under Nigerian Law', (2009) 28(2) J. Hum Ecol.

Okon, Emanuel E., 'The Legal Status of Sustainable Devlopment in the Nigerian Environmental Law', (2016) 1(2) AfeBabalola University Journal of Sustainable Development and Policy.

Mensah, Justice, 'Sustainable Development: Meaning, history, principle, pillars, and implications for Human Action: Literature Review', (2019) Cogent Social Science.

Verschuuren, Jonathan, 'Sustainable Development and the Nature of Environmental Legal Principles', (2006) (9)1 Potchefstroom Electtronic Law Journal.

\section{Research}

Adeoye R.O, Legal Analysis of NESREA on Environmental Protection and Climate Change in Nigeria, (PhD Law Thesis, University of Ilorin, Ilorin, Nigeria, 2017).

Adeoye, R.O., Environmental Rights and Sustainable Development, (LLM Seminar Paper, Faculty of Law, University of Ilorin, Nigeria).

Haris, Jonathan M., Basic Principles of Sustainable Environment: Global Development, (an Environmental Institute Working Paper 00-04, 2000).

Ladan, Mohammed Tawfiq, Legal Issues in Environmental Sanitation and Waste Management in Nigeria: Role of Environmental Courts, (Seminar paper presented to Magistrateson Environmental Sanitation Law, National Institute of advanced Legal Studies Abuja Nigeria, 2015), http.rssrn.com.doi.org.

\section{Internet Source}

T. Yusuf A., Implementing the nine Principles of a Bustainable Society: Can Nigerian Government Deliver?(2009).

$<\mathrm{http} /$ www.nigeriansinamerica.com/a rticle/264/1/implementing the- nineprinciples of $-\mathrm{a}$ - sustainable societycan- nigerian governmentdeliver/page1.htm> accessed 26/1/2020.

http://www.unece.org/envy/welcome.html,a ccessed January 26.

\section{Conference}

Oluwatoy in Adejowo-Osho, Evolution of Human Rights Approach to Environmental Protection, 22.

The United Nations Conference on Environment and Development 'The Rio Declaration'

UN.DocA/Conference.48/Rev, 20.

The United Nations Conference on Human Environment, 'Stockholm Declaration' (16 June1972),UN.Doc.A/Conf.48./14 /Rev.1 (UN. Pub. 73.11.A.14), 10.

\section{Law}

African Charter on Huma and Peoples Rights, Article 24.

The United Nations Convention on the Rights of the Child November 201989.

Environmental Impact Assessment Act1992, Section 14.

Environmental Impact Assessment Act1992, Section 14.

National policy on Environment in Nigeria 1988, Paragraph 30(A).

National Environmental (Soil and Flood Control) Regulations 2011.

The Constitution of the Federal Republic of Nigeria 1999(As amended), Section 20.

The National Environmental Standards Regulations Enforcement Agency Act 2007, section 2(1). 